\title{
Preparation of Microcrystalline Cellulose from Water Hyacinth Powder by Enzymatic Hydrolysis Using Cellulase of Local Isolate
}

\author{
Herman Suryadi ${ }^{1}$, Sutriyo $^{2}$, Hasty Ristina Sari ${ }^{1}$ and Dianah Rosikhoh ${ }^{1}$ \\ 'Laboratory of Microbiology and Biotechnology, Faculty of Pharmacy, Universitas Indonesia, Depok 16424, INDONESIA. \\ "Laboratory of Pharmaceutical Technology, Faculty of Pharmacy, Universitas Indonesia, Depok 16424, INDONESIA.
}

\begin{abstract}
Introduction: Microcrystalline cellulose is one of the cellulose derivatives widely used in the pharmaceutical industry as an excipient in the manufacture of tablets. Unfortunately, most of these filler materials are still largely imported. On the other hand, Indonesia has huge potential to generate microcrystalline cellulose from agricultural waste or weeds such as oil palm empty fruit bunch and water hyacinth. The purpose of this study was to find a potential cellulolytic mold and raw material for preparation of microcrystalline cellulose by enzymatic hydrolysis. Method: The potential cellulolytic mold was obtained from rotted oil palm trunk, and alpha cellulose was prepared by digesting raw material powder by the alkaline condition. Cellulase enzymes are obtained through extraction from the cellulolytic mold and used to treat alpha cellulose at a concentration of 2,6 and $10 \% \mathrm{v} / \mathrm{v}$, respectively. Then, the resulted microcrystalline cellulose was identified by SEM (Scanning Electron Microscope) and XRD (X-Ray Diffraction) and compared with reference Avicel pH 101. Results: The results showed that crude enzyme of isolated mold has better activity than
\end{abstract}

Trichoderma reesei enzyme, which produced a lower concentration of glucose. Conclusion: Based on the comparison of crystal morphology and diffractogram pattern, water hyacinth has a great potential which showed crystalline characteristic similar to microcrystalline cellulose reference (Avicel pH 101).

Key words: Water hyacinth, Microcrystalline cellulose, Cellulase, Trichoderma reesei.

Correspondence :

Herman Suryadi

Laboratory of Microbiology and Biotechnology, Faculty of Pharmacy, Universitas Indonesia, Depok 16424, INDONESIA.

Phone no: 62-21-7270031

Email: hermans001@yahoo.com

DOI: 10.5530/jyp.2017.1s.6

\section{INTRODUCTION}

Cellulose is a polymer of $\beta$-glucose with $\beta-1-4$ bonds between the units of glucose. Cellulose generally found in wood, cotton, and other lignocelluloses producing plants. Cellulose first isolated from wood in 1885 by Charles F. Cross and Edward Bevan. One of the cellulose derivatives often used in the pharmaceutical industry as an excipient in the manufacture of tablets by direct compression is microcrystalline cellulose (MC). Microcrystalline cellulose was first introduced in the early 1960s. ${ }^{1}$ Microcrystalline cellulose serves as a binder, and a filler material as well as crushers and has shattered a relatively short time and can improve the flow properties of the granules. ${ }^{2}$ The need of microcrystalline cellulose was supplied by importing from abroad that has an impact on the increase of price of drugs on the market.

Preparation of microcrystalline cellulose is generally used chemical processes by acid hydrolysis method, using a strong acid to remove amorphous part of cellulose to produce particles consisting of micro crystals. ${ }^{3,4}$ However, chemical hydrolysis requires high activation energy and generates waste (acid, base, and organic compounds) which is less environmentally friendly. Current Research is being developed for a method of production of microcrystalline cellulose using cellulase enzymes. The process uses a controlled parameter, namely $\mathrm{pH}$, temperature, and time. ${ }^{5}$ Enzymatic hydrolysis has several advantages over acid hydrolysis. In the enzymatic hydrolysis, sugar degradation does not occur and can take place at low temperatures with high yield. ${ }^{6}$

On the other hand water hyacinth population that continues to grow each day and a huge number of oil palm empty fruit bunch (OPEFB) waste are becoming a problem that must be solved. Some utilizations of water hyacinth are: as art paper, as raw material for making bioethanol, particle board, and membranes, ${ }^{7}$ while utilization of oil palm empty fruit waste is still limited. Based on its content, both sources of lignocellulosic materials has a high cellulose content composition. Water hyacinth has about $60 \%$ cellulose, $8 \%$ hemicellulose, and $17 \%$ lignin; while OPEFB waste has $41,30-46,50 \%$ cellulose, so they can be used to produce microcrystalline cellulose..$^{8-10}$ The purpose of this research was to find a potential cellulolytic mold and raw material for preparation of microcrystalline cellulose by enzymatic hydrolysis using crude enzyme of the potential isolate.

\section{MATERIALS AND METHODS}

Raw Materials and Microorganism water hyacinth raw material used in this study was obtained from Balai PenelitianTanaman Rempah dan Obat (Balitro), Bogor. Isolate of microorganisms derived from oil palm trunk, and stem of water hyacinth that had been rotted. Trichoderma reesei which obtained from collection of Sekolah Ilmu Teknologi Hayati (SITH), ITB, Bandung, was used as a reference culture. Medium of PDA was used for maintenance of the cultures.

\section{Tools and Instruments}

The tools used in this study were autoclave (Hirayama), oven (WTB Binder), analytical balance (Acculab), waterbath shaker, hotplate stirrer (Corning), pH meter (Eutech), sentrifugator (Kubota 6800), incubator (Memmert), vacuum oven (Hotpack), filter paper, ose, pipette volume and other glass wares commonly used in laboratories.

The instruments analysis used were UV-Vis spectrophotometer (Shimadzu), pH meter, Scanning Electron Microscope (JEOL), and X-ray diffractograf (Rigaku). 


\section{Chemicals}

Chemicals used in this study were sodium hydroxide (Bratachem), nitric acid (Merck), ethanol (Merck), acetate buffer, urea, medium potato dextrose agar (Difco ${ }^{\mathrm{r} x}$ ), media CMC order, media CMC liquid, congo red $0,1 \%$, tween 80 , buffer citrate phosphate $\mathrm{pH} 5$, Dinitrosalycilic acid, ammonium sulfate (Merck), sulfuric acid (Merck), potassium dihydrogen phosphate (Merck), calcium chloride monohydrate (Merck), magnesium sulfate heptahydrate (Merck), aquabidestilata (Otsuka).

\section{Screening of Cellulase Activity Based on Transparent Zone in CMC agar Medium}

Screening of cellulase activity was based on a transparent zone in the CMC agar medium. To see the ability of fungi to degrade, each crude enzyme extract as much as $5 \mu \mathrm{L}$ was injected to the paper disc using a micropipette in a petri dish containing media carboxy methyl cellulose (CMC), NaNO3, KH2PO4, KCl, MgSO4.7H2O, yeast extract, glucose and incubated at room temperature $\left(27-28^{\circ} \mathrm{C}\right)$ for $3-7$ days. The test was repeated twice for each isolate. Agar clear zone formation becomes clearer staining using Lugol. ${ }^{11}$ In addition, the petri dishes are also grown Trichoderma reesei as a comparison/reference culture. Fungal isolates which showed cellulolytic activity can be seen from the the formation of a clear zone around the colony. Isolate of cellulolitic mold obtained was then selected by the ratio between the diameter of the clear zone and diameter of colony.

\section{Preparation of Calibration Curve Standard Glucose}

Glucose standard curve was created by making a series of glucose standard solution: 75 ppm, 90 ppm, 105 ppm, 120 ppm, 135 ppm and 150 ppm, which showed absorption between 0.2 to 0.8 . Each glucose solution with a variety of different concentrations in distilled water was added with DNS $1 \%$ with a ratio of $1: 1$. Each solution was then heated in a water bath at temperature of $100^{\circ} \mathrm{C}$ for 15 minutes and the solution was allowed to stand to room temperature. The absorbance was measured at a wavelength of 510-520 $\mathrm{nm}$.

\section{Crude Enzyme Cellulase Preparation and Its Selection with Sugar Reduction Method}

A spore suspension was made by adding $5 \mathrm{~mL}$ aquabidest into test tubes containing slant culture of isolate in agar medium. Discratch the spores to blend with aquabidest. Then $10 \mathrm{~mL}$ of spore suspension in $0.1 \%$ tween 80 was added with nutrient broth solution, which composed of: yeast extract $200 \mathrm{mg}$. $300 \mathrm{mg}$ peptone, $\left(\mathrm{NH}_{4}\right)_{2} \mathrm{SO}_{4} 280 \mathrm{mg}, 200 \mathrm{mg} \mathrm{K \textrm {H } _ { 2 }} \mathrm{PO}_{4}$, $\mathrm{K}_{2} \mathrm{HPO}_{4} 200 \mathrm{mg}, 200 \mathrm{mg} \mathrm{MgSO}{ }_{4 \cdot 7} \mathrm{H}_{2} \mathrm{O}, \mathrm{CMC} 1 \% 5 \mathrm{~mL}$, and $0.1 \mathrm{M}$ acetate buffer $\mathrm{pH} 5$ to $200 \mathrm{~mL}$. The solution mixture was stirred at $150 \mathrm{rpm}$ for 120 minutes at room temperature. Then, a mixture of $30 \mathrm{~mL}$ of the solution was taken and centrifuged at $3000 \mathrm{rpm}$ for 10 minutes $4^{\circ} \mathrm{C}$

A spore suspension of fungal isolates were inoculated aseptically into each of the nutrient medium and incubated in the incubator with stirring for 72 hours ( 8 hours, $16,24,32,40,48,56,64,72)$ at $50^{\circ} \mathrm{C} 75 \mathrm{rpm}$. Every 8 hours as much as $2 \mathrm{~mL}$ sample was taken and then centrifuged at $5000 \mathrm{rpm}, 4^{\circ} \mathrm{C}$ for 15 minutes. Then, crude enzyme extract in the form of the supernatant was taken as $1 \mathrm{~mL}$.

Screening process quantitatively using UV-Vis spectrophotometry. Volume ratio of cellulose substrate solution, an enzyme extract, and DNS $1 \%$ was $2: 1: 3$. CMC as a substrate cellulose is dissolved in $0.2 \mathrm{M}$ phosphate buffer $\mathrm{pH}$ 5. The enzyme extract as much as $0.4 \mathrm{~mL}$ taken and put into a test tube. Then, $0.8 \mathrm{~mL}$ of the CMC was added to the test tube and incubated at $40^{\circ} \mathrm{C}$ for 30 minutes. After that, $1.2 \mathrm{~mL}$ of $1 \%$ DNS was added into a test tube and then heated at $100^{\circ} \mathrm{C}$ water bath for 15 minutes. The test samples are allowed to stand until they reach the room tempera- ture. The absorbance was measured at wavelength of about 510-520 nm (maximum wavelength), and glucose concentrations were calculated by equation of calibration curve.

\section{Optimization duration of hydrolysis}

Water hyacinth powder used here was powder that has delignified by heating in $17 \% \mathrm{NaOH}$, and used as substrates (alpha-cellulose). Crude enzyme extract of isolates and T.reese $i$ were prepared by centrifugation at $3000 \mathrm{rpm} 4^{\circ} \mathrm{C}$, for 10 minutes. For the measurement, 1 gram of alpha cellulose hyacinth dissolved in $10 \mathrm{~mL}$ of $0.1 \mathrm{M}$ acetate buffer $\mathrm{pH} 5$ and added $0.2 \mathrm{~mL}$ of the supernatant enzyme. The solution mixture was incubated at $50^{\circ} \mathrm{C} 160 \mathrm{rpm}$ for 12 hours with sampling every 2 hours and then added as much as $0.75 \mathrm{~mL}$ of $0.75 \mathrm{~mL}$ of $1 \% \mathrm{DNS}$. Then, the sample was heated for 15 minutes and allow to stand to room temperature. The absorbance was measured and calculated by equation of calibration curve.

\section{Extraction of a-Cellulose and Preparation of microcrystalline cellulose by Enzymatic Hydrolysis}

200 grams of hyacinth powder that has been sifted and then heated with $\mathrm{NaOH}$ solution $17.5 \% \mathrm{w} / \mathrm{v}$ for 5 hours at a temperature of $90^{\circ} \mathrm{C}$. Furthermore, the suspension was filtered and washed with aquadestilata to achieve a $\mathrm{pH}$ of 6-7. After that it was dried in an oven at $60^{\circ} \mathrm{C} .{ }^{8}$ The powder isolated was alpha cellulose and keep drying before hydrolyzed to produce microcrystalline cellulose.

In the process of enzymatic hydrolysis, the enzyme used were varied by volume in order to see the optimum conditions in the preparation of microcrystalline cellulose. About 2 grams of $\alpha$-cellulose hyacinth was dissolved in $20 \mathrm{~mL}$ of acetate buffer $(0.1 \mathrm{M}, \mathrm{pH} 5)$ and $0.4 \mathrm{~mL}$ crude enzymes from isolates, and stirred slowly. The mixture of solution was stirred at $160 \mathrm{rpm} 50^{\circ} \mathrm{C}$ for 1 hour. Then, the mixture was centrifuged at $10,000 \mathrm{rpm}$ (at a temperature of $7-10^{\circ} \mathrm{C}$ for 20 minutes). The residu settles down with aquadest was washed to remove residual enzyme on cellulose and then dried. ${ }^{5}$ The same processes were carried out using 1.2 $\mathrm{mL}$ and $2 \mathrm{~mL}$ crude enzyme of selected isolate.

The powder resulted was bleached using $20 \mathrm{~mL} \mathrm{H} 2 \mathrm{O} 23 \%$ at a temperature of $80^{\circ} \mathrm{C}$ for 1 hour. After that, the bleaching powder is filtered and washed few times with aquabidest then dried in oven.

\section{Analysis X-Ray Diffraction and Identification of Crystals by Scanning Electron Microscope (SEM)}

Crystal Analysis was performed using XRD (Rigaku Miniflex 600) with a voltage of $40 \mathrm{kV}$, the power of $600 \mathrm{~W}$, the electric current $15 \mathrm{~mA}$ and $\mathrm{Cu}$ radiation source at an angle $2 \Theta=0-70^{\circ} \mathrm{C}$.

For identification, samples were bonded with stable metal palladium, cleaned with a blower, and coated with gold and palladium in a pressurized machine, Dionspater 1492 x 102 atm. Samples were subsequently put into special room and then irradiated with electron beam powered $10 \mathrm{kV}$. The sample emit secondary electrons and electrons that bounce can be detected by a detector scientor which is then amplified by an electrical circuit that produces an image on a CRT (Catode Ray Tube). Shooting is done after selecting a specific part of the object (sample) and the desired magnification in order to obtain a good and clear photo. ${ }^{12}$

\section{RESULTS AND DISCUSSION}

\section{Screening Cellulase Activity based on Clear Zone in CMC Media}

Isolation of cellulolytic mold has already done in our preliminary study. In this study, screening for highest cellulase activity was carried out by 
the method of cellulose degradation. The activity of cellulase is indicated in the formation of a clear zone around the colony of fungi. The sample of cellulases used were the supernatant crude enzymes from each isolate of mold. The medium used was medium agar CMC with Lugol staining at the end after incubation. CMC (Carboxymethyl cellulose) is a derivative of cellulose that can be used as a medium for testing the activity of cellulase. The addition of Lugol serves as dye to make it easier to see and measure the clear zone formed. Lugol reagent will be bound at 1,4- $\beta$ glycoside on cellulose that will provide blue-black color. Meanwhile, transparent color showed that cellulose has been decomposed into monosaccharides that can not form a complex with iodine of lugol reagent. The ability to form clear zone on a specific media indicates that the fungus is able to produce the cellulolitic enzyme, cellulase.

From the results of measurements of clear zone, white isolate (IEP) and Trichoderma reesei (Figure 1A and 1C) showed a clear zone diameter of $0.25 \mathrm{~cm}$ and $0.15 \mathrm{~cm}$, while black isolate (IH) which derived from weathered oil palm trunk (Figure 1B) showed higher cellulolytic activity with a clear zone of $1.12 \mathrm{~cm}$. Other isolate with green pigment showed no activity (data not shown).

\section{Preparation of Glucose Standard Calibration Curve}

Standard solution of glucose $1500 \mathrm{mg} / \mathrm{mL}$ was used as the mother solution to make a standard solution of glucose each about $75 \mathrm{ppm}, 90 \mathrm{ppm}$, $105 \mathrm{ppm}, 120 \mathrm{ppm}, 135 \mathrm{ppm}$ and $150 \mathrm{ppm}$. Each of this solution was taken $1 \mathrm{ml}$ and added $1 \mathrm{~mL}$ of $1 \%$ DNS (1: 1). The solution will showed the orange color after heating. After cooling down to room temperature, the absorbance was measured by spektrophotometer UV - Vis at wavelength of 510-520 nm.DNS is a reagent with redox reactions at the aldehyde group sugars and oxidized to carboxylate. Meanwhile DNS as an oxidant is reduced forming 3-amino-5-nitrosalicylic acid. This reaction is run under alkaline conditions. When there is a reducing sugar in a sample, the DNS solution that was originally yellow will react with reducing sugars, causing the reddish orange color will be more intense color when the concentration of sugar is higher. DNS reagent consists of dinitrosalicylic acid, Na-K tartrate (Rochelle salt), phenols, Na bisulfite, and $\mathrm{NaOH}$. Na-K tartrate served to protect the reaction of dissolved oxygen. Phenol was used to increase the color intensity. Na bisulfite was used for stabilizing the color for their phenol. $\mathrm{NaOH}$ was used to achieve the basic conditions for the reaction to run and heating was needed to speed up the reaction. Based on spectrophotometry analysis, it was obtained an equation:

$y=0,0058 x-0,2111 ;$ with linear regression coefficient $r=0,9963$

\section{Selection of cellulase with Sugar Reduction Method and Spectrophotometry}

The results obtained from measurement of glucose concentration after treatment with different cellulase during 72 hour showed that all glucose concentrations rise and fall, not as stable as shown in Figure 2. Cellulase from Trichoderma reesei and white isolate (IEP) produced higher concentration of glucose in short time ( 8 hours) and kept stable enough until 56 hours. This suggested that the Trichoderma reesei and isolates IEP was not suitable for the purpose of this research because of high concentrations of glucose produced. Meanwhile, the desired result is a high cellulase activity with low enough concentration of glucose produced, which can be used to produce microcrystalline cellulose. From these results black isolate $(\mathrm{IH})$ was selected for further experiments.

\section{Extraction of Crude Enzyme and Optimization Duration of Hydrolysis}

The addition of $0.1 \%$ between 80 as surfactant to help pull out the enzyme. The extraction of the enzyme is done by centrifugation at 3000 rpm for 10 minute at $4^{\circ} \mathrm{C}$ to separate the supernatant (crude enzyme extract) and the cells molds. The extraction process is done at $4^{\circ} \mathrm{C}$ for keeping the stability of enzyme.

An optimization stage of hydrolysis was carried out using hyacinth powder that has been delignified with $17.5 \% \mathrm{NaOH}$ as the initial substrate of cellulose. The water hyacinth powder containing a-cellulose used as a raw material for the preparation of microcrystalline cellulose. Samples were incubated for 10 hours. Each sample was immediately added by DNS $1 \%$, measured by spectrophotometry and put into a linear equation.

\section{Preparation of a-Cellulose.}

About 200 grams of powder hyacinth was delignified with $17.5 \% \mathrm{NaOH}$. The use of $\mathrm{NaOH} 17.5 \%$ was intended to separate the $\alpha$-cellulose fraction (insoluble) from the soluble fraction ( $\beta$ and $\gamma$ form). Furthermore, the suspension is filtered and rinsed with distilled water to achieve a neutral $\mathrm{pH}$ and eliminate the other impurities. Then, it was dried in a vacuum oven. The result is a light brown powder (data not shown).

\section{Preparation of Microcrystalline Cellulose}

Variation of enzyme concentration $(2,6$, and $10 \% \mathrm{v} / \mathrm{v})$ was carried out by variation volume of crude enzyme added to 2 grams of alpha cellulose powder of hyacinth, and dissolved with $0.1 \mathrm{M}$ acetate buffer $\mathrm{pH} 5$ to $20,0 \mathrm{ml}$. Cellulase enzyme is active on the conditions around $\mathrm{pH} 5$. Reaction was run at $50^{\circ} \mathrm{C}$ for 1 hour by steering at $160 \mathrm{rpm}$ to accelerate the process of homogeneous blend of solvent and extraction of the enzyme. Separation was done by centrifugation at $10,000 \mathrm{rpm}, 7-10^{\circ} \mathrm{C}$ for 20 minutes to stop the enzymatic reaction. Sedimentation of hyacinth cellulose was filtered and rinsed with aquabidest few times to remove residual enzyme.

Bleaching was done by using $3 \% \mathrm{H} 2 \mathrm{O} 2$ at a temperature of $80^{\circ} \mathrm{C}$ for 1 hour. After that, the bleaching powder is filtered and washed few times with aquabidest, and finally dried in oven. The results of microcrystalline cellulose from water hyacinth can be seen in Figure 3.

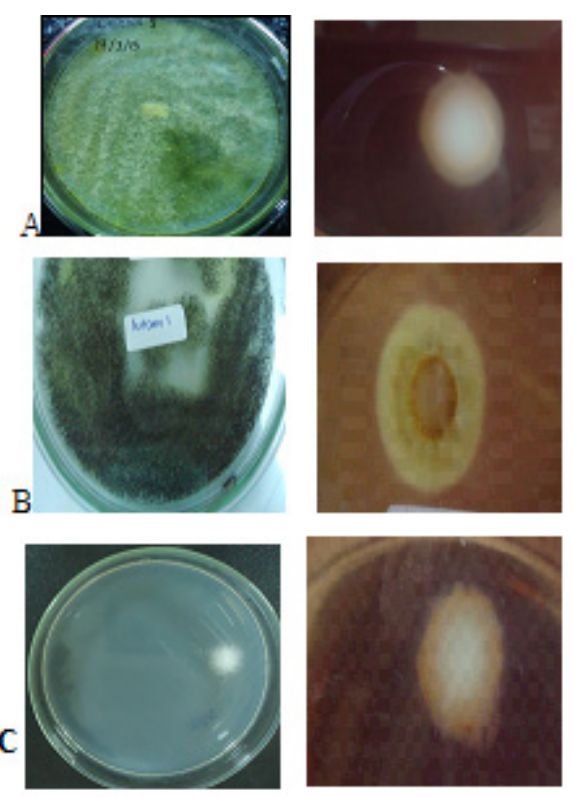

Figure 1: Colonies of Trichoderma reesei and isolates (left) and their cellulolytic activity (right). A, T.reesei; B, black isolate (IH) and C, white isolate (IEP). 


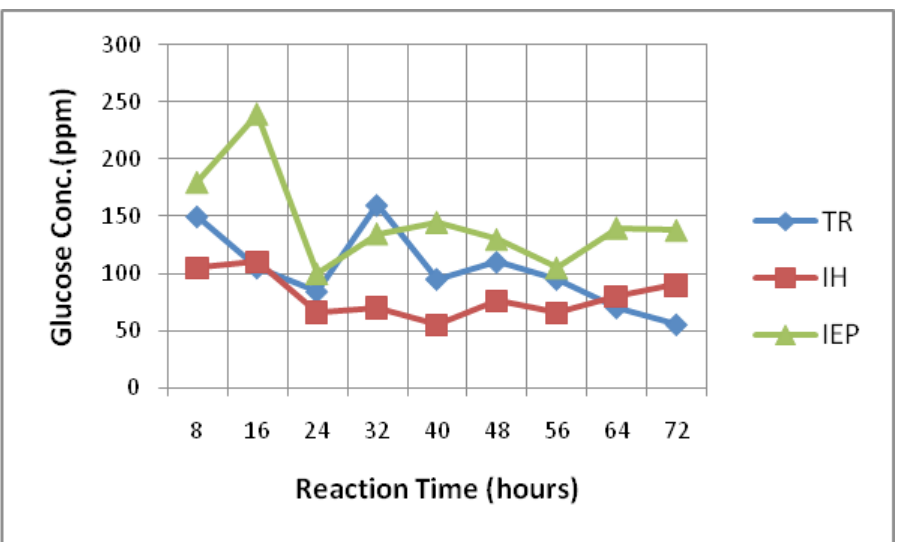

Figure 2: Glucose Concentration curve with DNS method using Trichoderma reesei (TR), Isolate IEP, and Isolate IH.

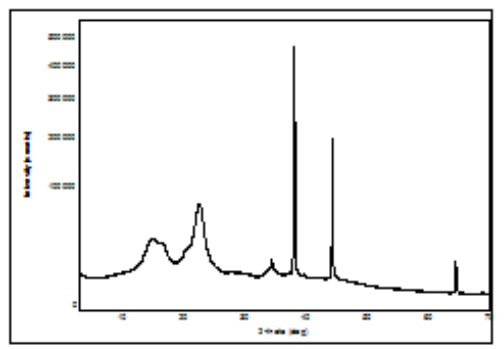

(a)

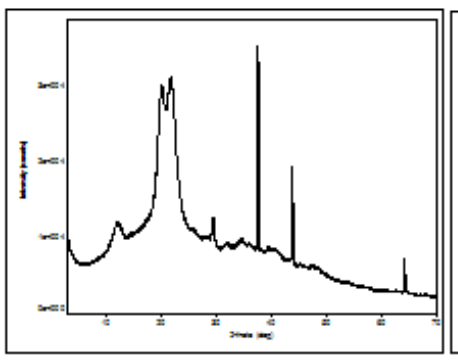

(b)

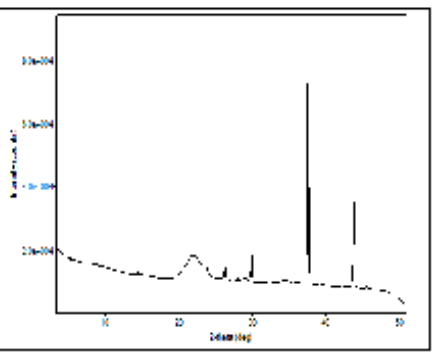

(c)
Figure 4: XRD diffractogram of Avicel pH 101 (a), Hydrolysis Results of Hyacinth powder (b) and Oil Palm Empty Fruit Bunch Powder (c).

Even though the colour of hyacinth powder has changed after hydrolysis and bleaching process, but it still need to optimize the bleaching process to get the similar color with reference microcrystalline cellulose (Avicel $\mathrm{pH}$ 101). Other researchers proposed to use grinding or homogenizing again after enzymatic and bleaching process to find the suitable size and properties of microcrystalline cellulose. ${ }^{5}$

\section{Analysis of crystal by X-Ray Diffraction (XRD)}

$\mathrm{XRD}$ analysis was conducted in this study to see the shape of the crystal samples compared to reference, Avicel pH 101. In general, the polymer material of MCC is semi-crystalline. It means that MCC still contain the amorphous part beside the dominant crystalline parts. The X-ray diffractogram of crystalline polymers produce sharp peaks; while the amorphous polymers tend to produce a widened or blunt peak (see Figure 4). In Avicel pH 101 that measured in this study (Figure 5.a) there is a typical pattern of a diffractogram, on $2 \theta$ value of 22.5 contained a sharp peak that shows the nature of the crystalline and on $2 \theta$ value of about 18 the blunt and widened peak or valley show amorphous nature. This

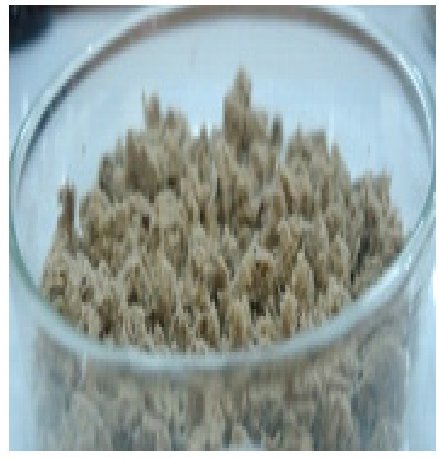

(a)

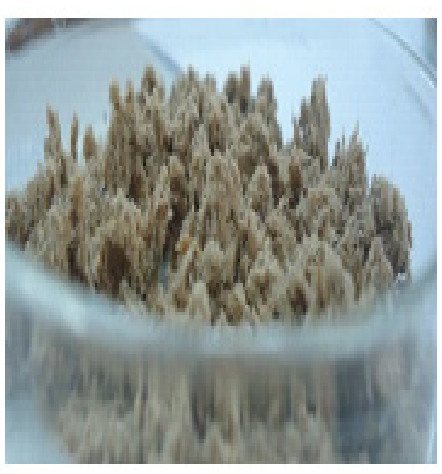

(b)
Figure 3: Microcrystalline cellulose powder from water hyacinth after Bleaching and hydrolysis with $6 \%$ (a) and $10 \%$ (b) crude enzyme of cellulase.
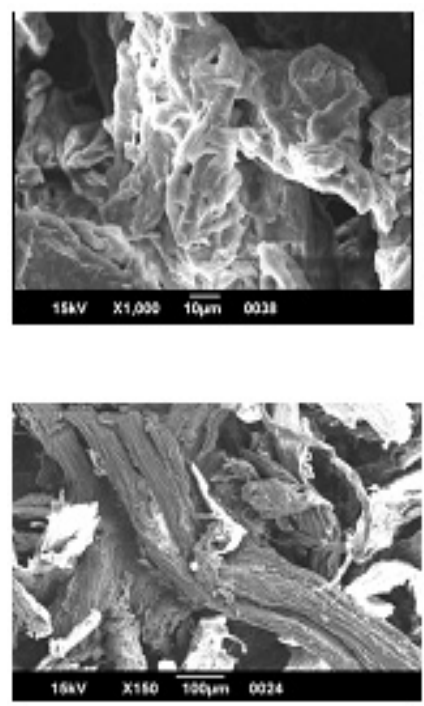

(c)

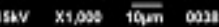

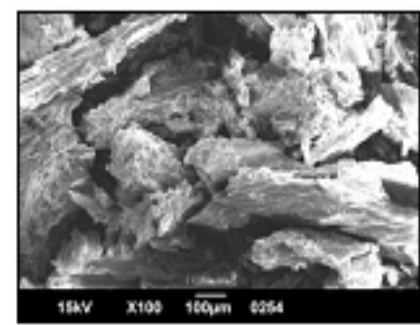

(a) (b)

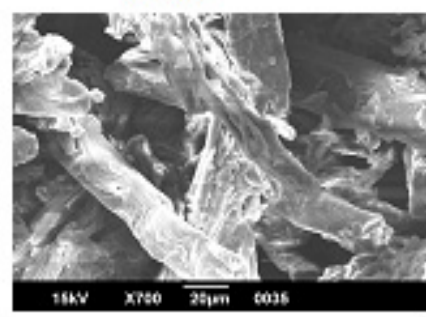

(d)
Figure 5: Result of SEM Analysis on Avicel pH 101, $M=1000 x(a)$, and Product of Hidrolysis with $2 \%$ (b), $6 \%$ (c) and $10 \%$ (v/v) (d) of crude enzyme (e); $M=700 x$

diffractogram standard of microcrystalline cellulose is suitable with diffractogram microcrystalline reference reported by other researchers. ${ }^{13}$ While the sample results of hydrolysis of hyacinth powder (Figure 5b) indicated $2 \theta$ value contained two sharp peaks 21.66 and 27. 57(twin peaks) but there is no blunt peak (amorphous form) at $2 \Theta$ of 18 , instead of valley between the peaks. Even though there is a little different in the pattern of each diffractogram, but they still has similarity in the properties of crystalinity, so they could still meet the criteria of the properties of microcrystalline cellulose standard that has a wide range of length chain 1000-1500 A, and the degree of polymerization between 200-300. ${ }^{2,5}$

The differences in the peak shape or diffract-o-gram pattern of sample hydrolysis of oil palm empty fruits bunch (Figure 5.c) with Avicel pH 101 indicating that it has a difference property of crystalline to Avicell reference, and also different size and degree of polymerization. Other possibility is product of microcrystalline from the sample of water hyacinth has properties of crystalline higher than standard Avicell pH101, as it showed less blunt or widened peak, and gave a value degree of crystalinity higher than standard Avicell pH 101, based on method of peak 
Table 1. Comparison of Intensity Values peaks at 2 theta angle and Degree of Crystalinity (DC) between Avicel pH 101 and Sample Hydrolysis of Hyacinth

\begin{tabular}{ccccc}
\hline & \multicolumn{4}{c}{ Type of MCC } \\
\cline { 2 - 5 } & \multicolumn{2}{c}{ Avicel pH 101 } & \multicolumn{1}{c}{ Hydrolysis result } \\
\hline $2 \theta(\mathrm{deg})$ & 22.54 & 18.5 & 21.66 & 16.5 \\
Intensity & 10000 & 3500 & 30000 & 10000 \\
DC(\%) & 65 & & 70 & \\
\hline
\end{tabular}

height. (Table 1). Degree of crystalinity can be calculated based on ratio of the difference intensities of crystalline peak and non-crystalline peak to total intensity of crystalline peak. ${ }^{14}$

\section{Analysis morphology of crystal by Scanning Electron Microscope (SEM)}

In this study, there are three sample and one reference standard were analyzed using SEM namely: hydrolyzed sample of hyacinth powder with $2 \%(\mathrm{v} / \mathrm{v})$ of the enzyme (Figure $5 \mathrm{~b})$, with $6 \%(\mathrm{v} / \mathrm{v})$ of the enzyme (Figure $5 \mathrm{c}$ ), and with $10 \%$ of enzymes (Figure $5 \mathrm{~d}$ ), as well as powder of Avicel $\mathrm{pH} 101$ as a reference (Figure 5a). Based on the results of SEM analysis in figure above, it can be seen that microcrystals of cellulose has already formed on samples, even with low concentration of enzyme for hydrolysis. However, the samples look like still contained lignin or wood fibers. This is possibly due to imperfection in delignification process.

To solve this problem, the process can be corrected by improving extraction and delignification process, i.e by increasing $\mathrm{NaOH}$ concentration or increasing duration process, which can increase the degree of crystalline.

Based on the results of SEM analysis in Figure 5(d), it can be seen that hydrolysis of alpha cellulose with $10 \% \mathrm{v} / \mathrm{v}$ crude enzyme was nearly perfect to produce morphology of microcrystalline cellulose similar to reference Avicel pH 101. ${ }^{2}$

\section{CONCLUSION}

As the conclusion, among the isolates and T. reesei have been screened, black isolate (IH) was considered as the best source of crude cellulase with suitable activity for preparation of microcrystalline cellulose. The optimum condition of enzymatic hydrolysis with cellulase with the substrate of water hyacinth was on the first hour when the glucose concentration is low, with concentration of enzymes used as much as $10 \%(\mathrm{v} / \mathrm{v})$. Based on the results of XRD and SEM analysis, there was a similar characteristic of crystalline between microcrystalline cellulose from hyacynth hydrolysis and reference Avicel pH 101.

\section{ACKNOWLEDGEMENT}

We would like to thanks Dean Faculty of Pharmacy, Universitas Indonesia and Head of Laboratory of Microbiology and Biotechnology for the facilities we used during our study.

\section{CONFLICT OF INTEREST}

This is a non-funding research work, that we declare there were no conflicts of interest.

\section{ABBREVIATIONS USED}

MC: Microcrystalline cellulose; CMC: Carboxy methyl cellulose; DNS: Dinitro salisilic acid; XRD: X-ray diffraction; SEM: Scanning electron microscope.

\section{REFERENCES}

1. Bimte NA, Tayade PT. Evaluation of Microcrystal Cellulosa Prepared From Sisal Fibers as aTablet Excipient: ATechnical Note. AAPS Pharm SciTech. 2007;8(1):18. Available from: https://www.ncbi.nlm.nih.gov/pubmed/17408230.

2. Rowe RC, Sheskey PJ, Ouinn ME. Handbook of Pharmaceutical Excipients $6^{\text {th }}$ ed. Washington DC and London: American Pharmacist Association and Pharmaceutical Press.,2009.

3. Gusrianto, P., Zulharmita, H. Rivai. Preparasi dan Karakterisasi Mikrokristalin Selulosa dari Limbah Serbuk Kayu Penggergajian, Jurnal Sains dan Teknologi Farmasi, 2011;16(2):180-8. Available from: Research Gate, https://www.researchgate.net/.../284409703_PREPARASI_DAN_KARAKTERISASI_MI.

4. Thoorens G, Fabrice K, Bruno L, Brian C, Brigitte E. Microcrystalline cellulose, a direct compression binder in a quality by design environment-A review. Int J Pharm. 2014;473(1):64 72.https://doi.org/10.1016/j.jpharm.2014.06.055; PMid:24993785.

5. Johnsy G, Ramana K.V., Bawa AS., Siddaramaiah. Bacterial cellulose nanocrystal exhibiting high thermal stability and their polymer nanocomposites. Int. J. Biol. Macromol., 2010;48(1):50-7.

6. Taherzadeh MJ, Karimi K. Acid-Based Hydrolysis Processes for Ethanol from Lignocellulosic Materials: A Review. Bioresources, 2007;2(3):472-99.

7. Rachmawaty, R., Metty M., and Slamet P. Sintesis selulosa diasetat dari eceng gondok (Eichhornia crassipes) dan potensinya untuk pembuatan membran. Tekn Kimia Dan Industri. 2013;2(3):8-16.

8. Gaonkar, S.M. dan Kulkarni, P.R. Micro crystalline cellulose from water hyacinth Acta Polymerica, 1986, . https://doi.org/10.1002/actp.1986.010370317.

9. Ahmed, AF and Abdel-Naby, M.A. Pretreatment and enzymic saccharification of water hyacinth cellulose. Carbohydr Polym. 2012;87(3):2109-13. https://doi. org/10.1016/j.carbpol.2011.10.033.

10. Syafwina $Y$, Honda T, Watanabe, M. Kuwahara. Pre-treatment of Oil Palm Empty Fruit Bunch by White-rot Fungi for Enzymatic Saccharification. Wood Res. 2002;89:19-20.

11. Teather RM, dan Peter J. Wood. Use of Congo Red-Polysaccharide Interactions in Enumeration and Characterization of Cellulolytic Bacteria from the Bovine. Appl Environ Microbiol. 1981;82:777-80.

12. Aulia F, Marpongahtun, Saharman, G. Studi Penyediaan Nanokristal Selulosa Dari Tandan Kosong Sawit (TKS). Jurnal Saintia Kimia. 2013;1(2).

13. Suvachittanont, Srikalaya, and Ratanapan, P. Optimization of Micro Crystalline Cellulose Production from Corn Cob for Pharmaceutical Industry Investment. Departement of Chemical Engineering, Kasetsart University, Bangkok, Thailand. J Chem Eng. 2013;7(12):1136-41.

14. Terinte N, Ibbet R, Schuster KC. Overview on Native Cellulose and Microcrystalline Cellulose I, Structure Studied by X-Ray Diffraction (WAXD): Comparison between Measurement Techniques, Lenzinger Berichte. 2011;89:118-31 